\title{
The Role of Nano-sized Manganese Coatings on Bone Char in Removing Arsenic(V) from Solution: Implications for Permeable Reactive Barrier Technologies
}

\author{
Jing Liu ${ }^{1,2}$, Lile He ${ }^{1}$, Faqin Dong ${ }^{1}$, Karen A. Hudson-Edwards ${ }^{3, *}$
}

${ }^{I}$ The Key Laboratory of Solid Waste Treatment and Resource Recycle, Ministry of Education, Southwest University of Science and Technology, Mianyang, 621010 China.

${ }^{2}$ The State Key Laboratory of Coal Resources and Safe Mining, China University of Mining \& Technology, Beijing, 100083 China.

3 Department of Earth and Planetary Sciences, Birkbeck, University of London, Malet St., London WC1E 7HX, UK.

Accepted by: Chemosphere

\begin{abstract}
Although the removal of $\operatorname{arsenic}(\mathrm{V})(\mathrm{As}(\mathrm{V}))$ from solution can be improved by forming metalbearing coatings on solid media, there has been no research to date examining the relationship between the coating and As(V) sorption performance. Manganese-coated bone char samples with varying concentrations of $\mathrm{Mn}$ were created to investigate the adsorption and desorption of $\mathrm{As}(\mathrm{V})$ using batch and column experiments. Breakthrough curves were obtained by fitting the ConvectionDiffusion Equation (CDE), and retardation factors were used to quantify the effects of the Mn coatings on the retention of $\mathrm{As}(\mathrm{V})$. Uncoated bone char has a higher retention factor (44.7) than bone char with $0.465 \mathrm{mg} / \mathrm{g}$ of $\mathrm{Mn}$ (22.0), but bone char samples with between $5.02 \mathrm{mg} / \mathrm{g}$ and 14.5 $\mathrm{mg} / \mathrm{g} \mathrm{Mn}$ have significantly higher retention factors (56.8 to 246). The relationship between retardation factor $(\mathrm{Y})$ and $\mathrm{Mn}$ concentration $(\mathrm{X})$ is $\mathrm{Y}=15.1 \mathrm{X}+19.8$. Between $0.2 \%$ and $0.6 \%$ of the sorbed As is desorbed from the Mn-coated bone char at an initial $\mathrm{pH}$ value of 4, compared to $30 \%$
\end{abstract}


from the uncoated bone char. The ability of the Mn-coated bone char to neutralize solutions increases with increased amounts of $\mathrm{Mn}$ on the char. The results suggest that using Mn-coated bone char in Permeable Reactive Barriers would be an effective method for remediating As(V)-bearing solutions such as acid mine drainage.

Keywords: Mn-coated bone char; As(V); sorption; breakthrough curve; neutralization; permeable reactive barrier $(\mathrm{PRB})$. 


\section{Introduction}

Arsenic (As) is a common, potentially toxic metalloid in acid mine drainage (AMD) (Bigham and Nordstrom, 2000). Aqueous As in AMD is derived from the oxidization of arsenic-containing sulfides such as As-bearing pyrite $\left(\mathrm{FeS}_{2}\right)$ or arsenopyrite (FeAsS) (Guo et al., 2014). Permeable reactive barrier (PRB) technology has been shown to be effective for treating $\mathrm{AMD}$, as most metalloid (e.g., As) and metallic elements are removed from solution by adsorption and precipitation (Benner et al., 1999). The choice of the material that fills the PRB is a key factor in determining the PRB's performance, service time and cost. Apatite is considered to be a good filling material due to its low cost and ability to remove metalloid and metallic elements from solution (Conca and Wright, 2006; Oliva et al., 2010). Apatite $\mathrm{II}^{\mathrm{TM}}$, for example, is a commercial material which is widely used for remediation of AMD and contaminated groundwater (Conca and Wright, 2006).

Bone char is a unique biological apatite which has a relatively pure composition $\left(\mathrm{Ca}_{5}\left(\mathrm{PO}_{4}\right)_{3} \mathrm{OH}\right)$ and is derived from the calcination of animal bone. It can also be used for the remediation of AMD due to its good hydraulic conductivity and its ability to neutralise $\mathrm{pH}$ and remove metalloid and metallic elements (Liu et al., 2012; Oliva et al., 2012). Sneddon et al. (2005) and Chen et al. (2008) used bone char to remove $\mathrm{As}(\mathrm{V})$ in the concentration range $4-100 \mathrm{mg} / \mathrm{L}$ and $0.5-1.5 \mathrm{mg} / \mathrm{L}$, and showed that it is a good sorbent for $\mathrm{As}(\mathrm{V})$ in the $\mathrm{pH}$ range 2-5. Liu et al. (2014a) investigated As(V) transport in bone char column experiments and showed that the retention ability of bone char on $\mathrm{As}(\mathrm{V})$ was 1.9 times higher than that of limestone. Although bone char has been shown to have a better removal ability for As compared to natural limestone and activated carbon (Davis et al., 2007; Gu et al., 2005), its removal capacity still needs to be improved in order to enhance its effectiveness and increase the lifetimes of PRB systems.

Surface coating technology has increasingly been used to improve the adsorption performance of low-cost synthetic and natural mineral materials. This technology involves the formation of poorly crystalline metal-bearing coatings on the surface of these media to increase the effectiveness 
of removal of inorganic contaminants such as As (Maji et al., 2011; Maji et al., 2012) and uranium (Logue et al., 2004). The coatings are commonly enriched in iron (Fe; Chang et al., 2008), manganese (Mn; Chang et al., 2008; Hu et al., 2004) and aluminium (Al; Heidari et al., 2011). Manganese coating technology is one of the most widely used to remove As because the Mnbearing coatings can also oxidize arsenite to arsenate, the less toxic form of As and the form more easily sorbed to substrates (Maliyekkal et al., 2006; Manning et al., 2002; Tournassat et al., 2002). For example, Tournassat et al. (2002) found that birnessite $\left(\mathrm{Na}_{4} \mathrm{Mn}_{14} \mathrm{O}_{27} \cdot 9 \mathrm{H}_{2} \mathrm{O}\right)$ oxidized $\mathrm{As}(\mathrm{III})$, and that the resultant $\mathrm{As}(\mathrm{V})$ was taken up in $\mathrm{As}(\mathrm{V})$-bearing $\mathrm{Mn}(\mathrm{II})$ oxides after $583 \mathrm{~h}$ of batch experiments.

Manganese is the third most common metallic cation in AMD after Fe and Al (Robinson, 2010). Manganese is less efficiently removed from AMD solutions than Fe due to its higher oxidationreduction potential and $\mathrm{pH}$ neutralization requirements (Sikora et al., 2000). However, precipitation of co-existing $\mathrm{Mn}$ and $\mathrm{Fe}$ cations in $\mathrm{AMD}$ as oxides can result in passivation of the filling media and clogging of PRBs, which in turn can reduce the neutralization ability and permeability (Rötting et al., 2008a; Rötting et al., 2008b; Santoro et al., 1987).

These metallic coatings can enhance the retention ability for contaminants. For example, recent work has shown that bone char is a suitable material for the removal of Mn from AMD effluents in Brazil (Sicupira et al., 2014). It is therefore possible that Mn-coated bone char could remove Mn and also increase the adsorption capacity for other metalloid and metallic elements. For example, As concentrations in AMD in gold mines in the northwest of Sichuan province, China, can reach 1.1 $\mathrm{mg} / \mathrm{L}$ (Liu et al., 2012). Bone char is the main byproduct of Sichuan province, where it is used as an agricultural soil fertilizer. This bone char has previously been shown to have good capacity for As adsorption (Liu et al., 2012). To build on this study by continuing to investigate methods for remediating these As-rich AMD solutions, we used Mn-coated bone char samples with different Mn concentrations to experimentally investigate the effects of the coating on As(V) adsorption behaviour, including the maximal adsorption, retardation ability, and desorption and neutralization 
potential. We also determined the ability of Mn-coated bone char to sorb As(V) from neutral $\mathrm{pH}$ waters $(\mathrm{pH} \approx 7.1)$, since some mine waters have these $\mathrm{pH}$ values (Nordstrom, 2011). The transport behaviour of $\mathrm{As}(\mathrm{V})$ was investigated using bone char-filled column experiments, in which the corresponding relationship of the coating and the retention ability of $\mathrm{As}(\mathrm{V})$ was described quantitatively. As laboratory studies have also demonstrated that bone char is highly porous and is able to neutralize acidic solutions (Liu et al., 2012; Oliva et al., 2012), we also determined the neutralization potential of the Mn-coated bone char. The results give new perspectives on, and knowledge of, $\mathrm{As}(\mathrm{V})$ transport and retention within PRBs when Mn-bearing coatings develop on the bone char filling materials.

\section{Materials and methods}

\subsection{Manganese-coated bone char preparation}

Bone char was obtained from Sichuan Biochemistry Co. Ltd in China. Sichuan is the site of the largest animal husbandry operation in China, where bone char is mainly used for preparing biological products and soil fertilizers. For this study, the bone char was ground and passed through a $425-850 \mu \mathrm{m}(20-40$ mesh) sieve to ensure that the end product had good hydraulic conductivity for the experiments. Laser size analysis (LS 13 320, Beckman Coulter Co., Ltd.) showed that the mean size of these bone char particles is $726 \mu \mathrm{m}\left(\mathrm{d}_{10}: 95 \mu \mathrm{m}, \mathrm{d}_{50}: 740 \mu \mathrm{m}, \mathrm{d}_{90}: 1252 \mu \mathrm{m}\right)$. Previous work has demonstrated that the bone char is relatively pure hydroxyl apatite $\left(\mathrm{Ca}_{5}\left(\mathrm{PO}_{4}\right)_{3} \mathrm{OH}\right)$ and composed of $\mathrm{CaO}$ (57.03 wt. \%), $\mathrm{P}_{2} \mathrm{O}_{5}$ (40.25 wt. \%), $\mathrm{MgO}$ (1.22 wt. \%) and other components (1.5 wt. \%) based on X-ray diffraction and X-ray fluorescence analysis (Liu et al., 2014b).

In order to investigate the influence of Mn-rich coatings with different concentrations of Mn on the bone char's ability to sorb As(V), a series of solutions with different Mn concentrations were prepared by dissolving appropriate amounts of $\mathrm{MnSO}_{4}(0,0.4,2,4,8,15,25,30 \mathrm{~g} / \mathrm{L} \mathrm{Mn}) .200 \mathrm{~mL}$ of each Mn-bearing solution were mixed with $10 \mathrm{~g}$ of bone char to form a Mn-bearing coating. The suspensions were then oscillated at $150 \mathrm{rpm}$ and $35^{\circ} \mathrm{C}$ for one day to attempt to develop uniform 
Mn coatings on the bone char particles. The Mn-coated bone char samples were then separated by vacuum filtration, washed several times with distilled water and dried at $85^{\circ} \mathrm{C}$ for one day. The samples were stored in a desiccator before being analysed.

\subsection{Coating characterization}

The surface areas of the uncoated and Mn-coated bone char samples were measured using the BET-nitrogen method (Quantachrome Autosorb-1MP USA). Surface morphologies and chemical compositions were observed and analysed with SEM-EDX using a Leo Ultra 55 FEG SEM equipped with an Oxford Inca EDX system, operated at $20 \mathrm{kV}$ with a WD=10 mm (EDX). To further analyse the chemical composition of the coatings, the samples were digested according to the following procedure: (1) uncoated and Mn-coated bone char samples were ground and passed through a 100 mesh sieve, and $0.100 \mathrm{~g}$ of the resultant material was placed in a digestion tube; (2) 6 $\mathrm{mL}$ aqua regia $\left(1: 3 \mathrm{v} / \mathrm{v} \% \mathrm{HNO}_{3}\right.$ and $\left.\mathrm{HCl}\right)$ and $2 \mathrm{~mL} \mathrm{HF}$ were added to the tubes and allowed to rest for 30 minutes; (3) the tubes were digested in a microwave accelerated reaction system for 55 minutes (MARS 240/50, CEM); (4) the acid was dried using an electrothermal digestion device for 3 h. Procedures (3) and (4) were repeated until the ivory-coloured solutions became transparent. All experiments were carried out in triplicate and blanks were inserted in the experimental runs. Manganese concentrations of the digestion solutions and the blanks were measured by inductively coupled plasma emission spectrometry (ICP-AES, iCAP6500, ThermoFisher).

\subsection{Batch adsorption and desorption experiments}

For the batch adsorption and desorption experiments, we adopted the 1:10 solid:solution ratio used in our previous study (Liu et al., 2014a). Kinetic adsorption studies were carried out to determine the adsorption equilibrium time before isothermal adsorption and corresponding desorption (at $\mathrm{pH} \approx 7.1$ and using ultra-pure water). $10 \mathrm{~g}$ of each bone char sample was mixed with $200 \mathrm{~mL}$ of $10 \mathrm{mg} / \mathrm{L} \mathrm{As}(\mathrm{V})$ solution with an initial $\mathrm{pH}$ of 4, and the suspension solutions were 
agitated at $150 \mathrm{rpm}$ and below $25^{\circ} \mathrm{C}$ to ensure that the adsorption reached equilibrium. The stock solution of $1 \mathrm{~g} / \mathrm{L} \mathrm{As}(\mathrm{V})$ was prepared by dissolving $4.1644 \mathrm{~g}$ of analytical grade $\mathrm{Na}_{2} \mathrm{HAsO}_{4} \cdot 7 \mathrm{H}_{2} \mathrm{O}$ (Alfa Aesar Company) in ultra-pure water, and $\mathrm{pH}$ values were adjusted using diluted $\mathrm{HNO}_{3}$. The solutions were passed through $0.45 \mu \mathrm{m}$ filters at different time intervals $(30,60,120,480,1440$, 2160 and $2880 \mathrm{~min}$ ) and analysed for As using Inductive Coupled Plasma Emission Spectrometry (ICP-AES, Icap6500 ThermoFisher). We used the same solid:solution ratios of 1:10, initial pH value of 4 and $\mathrm{As}(\mathrm{V})$ concentrations of $0.5,2,4,6,8,10,15,20,3040,50,60,80,100,120,150$ and $200 \mathrm{mg} / \mathrm{L}$ for both the adsorption and desorption experiments. Other experimental conditions were same as those in the kinetic adsorption experiments. The bone char was separated from the suspension solutions using a syringe after $48 \mathrm{~h}$ of equilibrium time, and dried at $85^{\circ} \mathrm{C}$ for one day. The As-sorbed bone char was then dispersed in $200 \mathrm{~mL}$ distilled water and agitated for another $48 \mathrm{~h}$ at the same experimental conditions. We term this process desorption of the As-sorbed, Mn-coated bone char. Suspension solutions also were filtered and analysed to evaluate the release of As from the Mn-coated bone char samples compared to the As-sorbed, uncoated bone char samples. Because we did not measure the As speciation on the Mn-coated solids or in the desorption solutions, we are not able to confirm that the As desorbed was $\mathrm{As}(\mathrm{V})$. For this reason, we refer to As rather than $\operatorname{As}(\mathrm{V})$ when discussing the desorption experiments.

\section{4. $p H_{P Z C}$ of uncoated bone char}

The point of zero charge (PZC) of the uncoated bone char was determined using the method described by Al-Degs et al. (2008). $10 \mathrm{~g}$ of uncoated bone char was placed in an Erlenmeyer flask with $200 \mathrm{~mL}$ of $0.1 \mathrm{M} \mathrm{KNO}_{3}$ solution. The resulting suspension was shaken for $24 \mathrm{~h}$ at $150 \mathrm{rpm}$ to allow for complete hydration of the solid surface, before being passed through a $0.45 \mu \mathrm{m}$ membrane filter. The final $\mathrm{pH}$ value of the supernatant liquid was measured, and the $\mathrm{pH}_{\mathrm{PZC}}$ of the bone char was determined using the $\mathrm{pH}_{\text {drift_curve }}\left(\mathrm{pH}_{\text {initial }} \mathrm{l}\right.$ vs $\left.\mathrm{pH}_{\text {final }}\right)$. 


\subsection{Column experiments and breakthrough curves of $A s(V)$}

Column experiments were carried out in laboratory scale glass columns with inside diameters of 2.1 $\mathrm{cm}$ and lengths of $22 \mathrm{~cm}$, previously described by Liu et al. (2014a). The porosity of the filled column was 0.6 , and the pore volume was $41.5 \mathrm{~mL}$. Arsenic(V) solutions with initial concentrations of $10 \mathrm{mg} / \mathrm{L}$ and $\mathrm{pH} 4$ were pumped through uncoated and Mn-coated bone char-filled columns at a constant flow rate of $213 \mathrm{~mL} / \mathrm{h}$ using a peristaltic pump working in an up-flow mode. Effluent samples were collected every hour. The sample were passed through a $0.45 \mu \mathrm{m}$ filter and analysed for As by ICP-AES.

Common factors affecting the transport of contaminant include convection, mechanical dispersion and adsorption. The retention ability of sorbents can be compared quantitatively using retardation factors, which can give insights into the transport behaviour of metalloid and metallic elements. Retardation factors describe contaminant transport velocities with respect to the flow velocity of water and they quantitatively reflect the retention ability of the sorbing materials on solutes. We therefore quantitatively compared the transport behaviour of As(V) in the different $\mathrm{Mn}$ coated bone char samples using such retardation factors. The transport behaviour of $\mathrm{As}(\mathrm{V})$ in the bone char column can be described by the conventional Convection Dispersion Equation (CDE) (Li et al., 2009; Liu et al., 2014b):

$$
\frac{\partial C}{\partial t}=\frac{D_{L}}{R_{f}} \frac{\partial^{2} C}{\partial x^{2}}-\frac{V_{x}}{R_{f}} \frac{\partial C}{\partial x}
$$

The retardation factor $\left(\mathrm{R}_{\mathrm{f}}\right)$ in above Eq. 1 can be calculated using the experimental breakthrough curves. In the equation, $C$ is contaminant concentration $(\mathrm{mg} / \mathrm{L})$, the $\mathrm{As}(\mathrm{V})$ concentration is $10 \mathrm{mg} / \mathrm{L}$, $\mathrm{V}_{\mathrm{x}}$ is the Darcy velocity $\left(\mathrm{V}_{\mathrm{x}}=\right.$ flow quantity/cross area, $\left.\mathrm{cm} / \mathrm{s}\right), \mathrm{t}$ is time $(\mathrm{s}), \mathrm{x}$ is the coordinate in the direction of flow, $\mathrm{D}_{\mathrm{L}}$ is the longitudinal dispersion coefficient $\left(\mathrm{cm}^{2} / \mathrm{s}\right)$. The analytic solution for above CDE equation is obtained as follows: 


$$
\frac{C_{e}}{C_{0}}=0.5 \operatorname{erfc}\left(\frac{P e^{1 / 2}\left(1-\frac{V_{x} t}{L R_{f}}\right)}{2\left(\frac{V_{x} t}{L R_{f}}\right)^{1 / 2}}\right)
$$

where $\mathrm{C}_{0}$ is the concentration at the inlet at $\mathrm{x}=0, \mathrm{C}_{\mathrm{e}}$ is the concentration at the outlet at $\mathrm{x}=\mathrm{L}, \mathrm{Pe}$ is the Plect number, and the $\operatorname{erfc}()$ is the complementary error function. Equation (2) describes the ratio of contaminant concentrations of the outlet and the inlet. The corresponding retardation factor can be obtained by fitting the experimental data to the CDE model.

\subsection{Acid and alkali resistance tests}

Solutions of different ionic strength $(\mathrm{I}=0 \mathrm{mM}, 0.1 \mathrm{mM}$ and $2 \mathrm{mM})$ were prepared by adding appropriate volumes of $0.1 \mathrm{~mol} / \mathrm{L} \mathrm{NaNO}_{3}$. The $\mathrm{pH}$ values of these solutions were adjusted to 2 and 12 by $\mathrm{HNO}_{3}$ and $\mathrm{NaOH}$ solutions, to respectively represent acidic and alkaline mine water environments. $10 \mathrm{~g}$ of each of the uncoated bone char and the Mn-coated bone char samples was mixed with $200 \mathrm{~mL}$ of these solutions in an Erlenmeyer flask. The suspension solutions were agitated at $25^{\circ} \mathrm{C}$ at $150 \mathrm{rpm}$ for $48 \mathrm{~h}$. The solutions were then filtered using a $0.45 \mu \mathrm{m}$ membrane and analysed for $\mathrm{Mn}$ and $\mathrm{Ca}$ by ICP-AES. Concentrations of released $\mathrm{PO}_{4}{ }^{3-}$ were analysed using the molybdenum blue colorimetric method (Clesceri et al., 1989).

\subsection{Neutralization ability of Mn-coated bone char}

The Mn-bearing coatings could potentially change not only the adsorption capacity of the bone char for sorbing As(V), but also its neutralization ability. To evaluate this possibility, $0.5 \mathrm{~g}$ of each Mn-coated bone char sample was mixed with $50 \mathrm{~mL}$ of ultra-pure water, and the initial $\mathrm{pH}$ of water was adjusted to $2.00 \pm 0.05$ with 10 vol.\% $\mathrm{HNO}_{3}$. Dynamic $\mathrm{pH}$ variations of the suspension solutions were measured with an automatic titrator (Mettler Toldeo T50), with data collected every $30 \mathrm{~s}$. The duration of the whole neutralization process was $2.2 \mathrm{~h}$. 


\section{Results and Discussion}

\subsection{Characterization of uncoated and Mn-coated bone char}

A total of seven Mn-coated bone char samples were prepared (samples $\mathrm{B}_{1}-\mathrm{B}_{7}$, Table 1), and pristine, uncoated bone char was used as a control (sample $\mathrm{B}_{0}$, Table 1). X-ray diffraction analysis (data not shown) reveals that all of the samples contain relatively pure hydroxylapatite $\left(\mathrm{Ca}_{5}\left(\mathrm{PO}_{4}\right)_{3} \mathrm{OH}\right)$. No crystalline Mn-bearing phases were distinguished at the limit of XRD detection. SEM analysis shows that nano-sized particles are present on the surfaces of the apatite in all of the coated samples (Fig. 1). The abundance of these nanoparticles increases with respect to the initial $\mathrm{Mn}$ concentrations used to make the Mn-coated samples. In sample $\mathrm{B}_{1}$ the particles are elongate and lath-like and are larger than those in samples B2 to B7, which resemble flattened spheres (Fig. 1).

Manganese concentrations obtained by SEM-EDX for samples $\mathrm{B}_{3}$ to $\mathrm{B}_{7}$ are higher than those determined the wet chemical analysis (Table 1), which is likely due to the relatively shallow surface profile analysed by SEM-EDX. The SEM-EDX analyses also suggest that the nanoparticles shown in Figure 1 are Mn-bearing. SEM-EDX Mn concentrations increase from 0\% to $47.3 \%$ in samples $\mathrm{B}_{0}$ to $\mathrm{B}_{7}$, whereas the bulk Mn concentration determined by wet chemical analysis increases from 0.025 to $14.5 \mathrm{mg} / \mathrm{g}$. Corresponding linear relations between the initial $\mathrm{Mn}$ concentrations and the bulk Mn concentrations are: $Y=0.26 X\left(R^{2}=0.86\right)$ and $Y 2=0.50 X\left(R^{2}=0.91\right)$, respectively, where $Y$ and $\mathrm{Y} 2$ is the Mn content obtained by EDX and wet chemical analysis, respectively, and $\mathrm{X}$ is the initial Mn concentration.

The surface area of the uncoated bone char is $1.51 \mathrm{~m}^{2} / \mathrm{g}$, and those of the Mn-coated samples increase from $2.69 \mathrm{~m}^{2} / \mathrm{g}$ to $4.60 \mathrm{~m}^{2} / \mathrm{g}$ with increasing amounts of $\mathrm{Mn}$ in the initial solutions $(0.4 \mathrm{~g} / \mathrm{L}$ to $7.85 \mathrm{~g} / \mathrm{L}$, Table 1 ). These increasing surface areas are likely due to increased amounts of $\mathrm{Mn}$ bearing nanoparticles on the bone char surfaces (Fig. 1). However, when initial Mn concentrations exceed $7.85 \mathrm{~g} / \mathrm{L}$, surface areas decrease (to $4.00 \mathrm{~m}^{2} / \mathrm{g}$ and $4.31 \mathrm{~m}^{2} / \mathrm{g}$ with initial $\mathrm{Mn}$ of 11.8 and 14.6 $\mathrm{g} / \mathrm{L}$, respectively; Table 1), possibly due to the Mn-bearing precipitates forming larger particles, or 
to the nanoparticles coalescing.
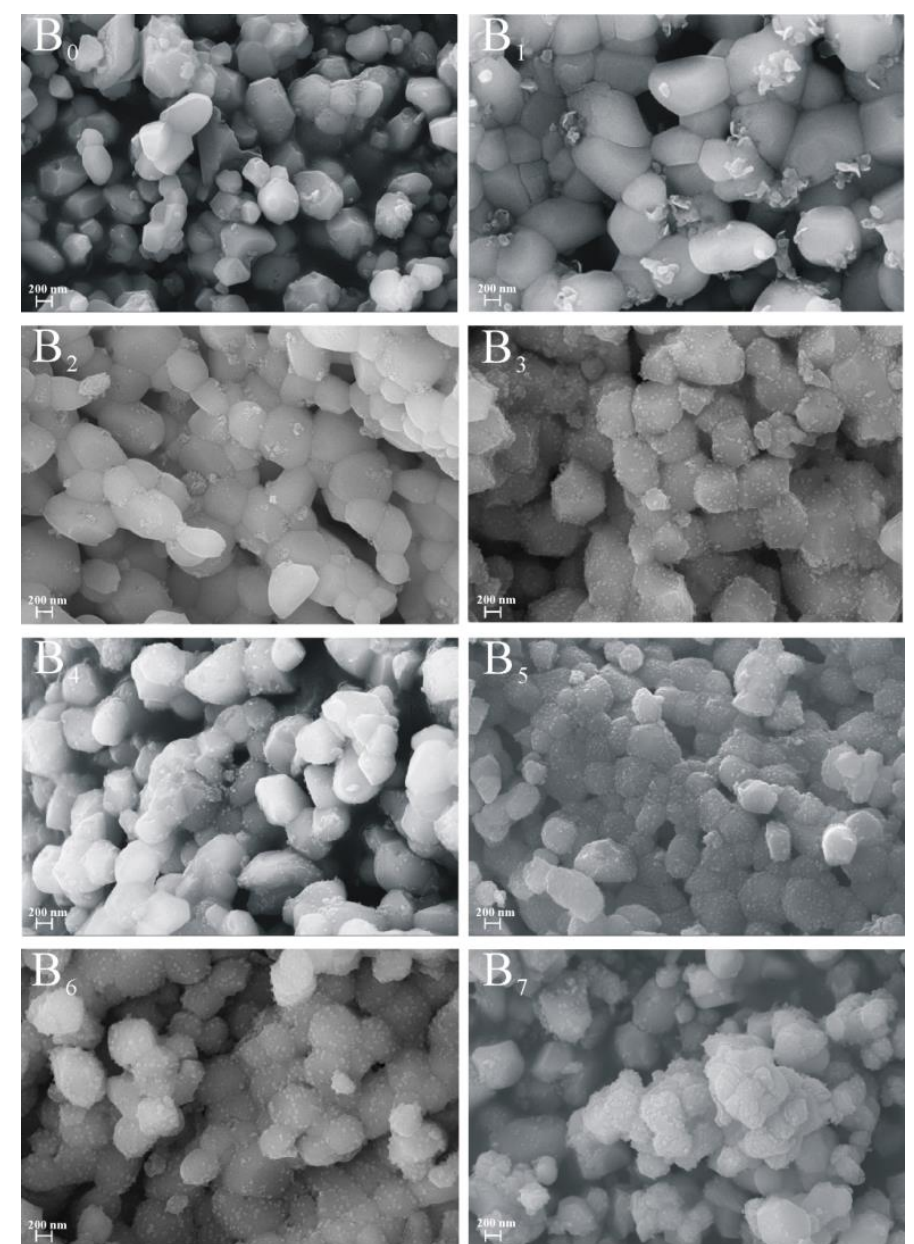

Fig. 1. SEM images of uncoated and Mn-coated bone char samples.

\subsection{Isothermal adsorption models}

Langmuir adsorption models were originally formulated to describe the adsorption of gas molecules to solid surface, but they also often used in the adsorption of dissolve ions on adsorbents. The maximum adsorption capacities of solutes on adsorbents can be obtained mathematically using this model. The Freundlich isotherm model is a nonlinear equation and formulated based on the assumption of parabolic adsorption. The Langmuir and Freundlich models are respectively defined as:

$Q_{e q}=\frac{Q_{\max } K C}{1+K C}$ (Langmuir model) 
where $\mathrm{Q}_{\mathrm{eq}}$ is the quantity of solute (As) sorbed per unit weight of solid adsorbent, $\mathrm{Q}_{\max }$ is the maximum sorption capacity and $\mathrm{K}$ is an energy term which describes the magnitude of the initial slope that represents the affinity between solute and minerals.

$\mathrm{q}_{\mathrm{i}}=\mathrm{KC}_{\mathrm{i}}^{\mathrm{n}} \quad$ (Freundlich model)

where $\mathrm{K}$ and $\mathrm{n}$ are adjustable and positive parameters which have no physical meaning. The term $\mathrm{n}$ can be an index describing the heterogeneity of the adsorption site on the adsorbent surface.

Table 1. Characteristics of uncoated and Mn-coated bone char samples.

\begin{tabular}{|c|c|c|c|c|}
\hline Sample & $\begin{array}{c}\text { Initial Mn } \\
\text { concentration (g/L) }\end{array}$ & $\begin{array}{c}\text { Solid composition } \\
\text { by SEM-EDS } \\
\text { analysis (wt\%) }\end{array}$ & $\begin{array}{c}\text { Solid composition } \\
\text { by wet chemical } \\
\text { analysis (mg/g) }\end{array}$ & BET(m²/g) \\
\hline $\mathrm{B}_{0}$ & 0 & $0 \%$ & 0.02 & 1.51 \\
\hline $\mathrm{B}_{1}$ & 0.4 & $0 \%$ & 0.47 & 2.69 \\
\hline $\mathrm{B}_{2}$ & 2 & $4.15 \%$ & 4.85 & 4.24 \\
\hline $\mathrm{B}_{3}$ & 4 & $10.9 \%$ & 6.79 & 4.15 \\
\hline $\mathrm{B}_{4}$ & 8 & $16.1 \%$ & 5.02 & 4.37 \\
\hline $\mathrm{B}_{5}$ & 15 & $12.3 \%$ & 7.85 & 4.60 \\
\hline $\mathrm{B}_{6}$ & 25 & $30.1 \%$ & 11.8 & 4.00 \\
\hline $\mathrm{B}_{7}$ & 30 & $47.3 \%$ & 14.6 & 4.31 \\
\hline
\end{tabular}

\subsection{Arsenic(V) adsorption performance of Mn-coated and uncoated bone char}

The maximum As adsorption capacity of the uncoated bone char (sample $\mathrm{B}_{0}$ ) was determined to be $0.12 \mathrm{mg} / \mathrm{g}$ using the Langmuir isotherm adsorption equation (Table 2). Adsorption capacities were determined using the batch experiment data to better understand the effect of the Mn-bearing coatings on adsorption (Fig. 2). The maximum adsorption capacities samples gradually increase 
from $B_{0}$ to $B_{4}(0.12 \mathrm{mg} / \mathrm{g}$ to $0.77 \mathrm{mg} / \mathrm{g})$, and then dramatically increase from $B_{5}$ to $B_{7}$, reaching 9.46 $\mathrm{mg} / \mathrm{g}$, which is 79 times higher than the uncoated bone char (Table 2). Adsorption capacity is positively related to surface area up to sample $B_{4}$, but not for samples $B_{5}$ to $B_{7}$, when it capacity greatly exceeds surface area (Table 1,2). Statistical tests for the relation coefficient shows the significant level $(\mathrm{P})$ is $0.08(>0.05)$, which indicates that there is no significant difference between the results for the Langmuir and Freundlich models and thus, that they can both describe the adsorption process of $\mathrm{As}(\mathrm{V})$.
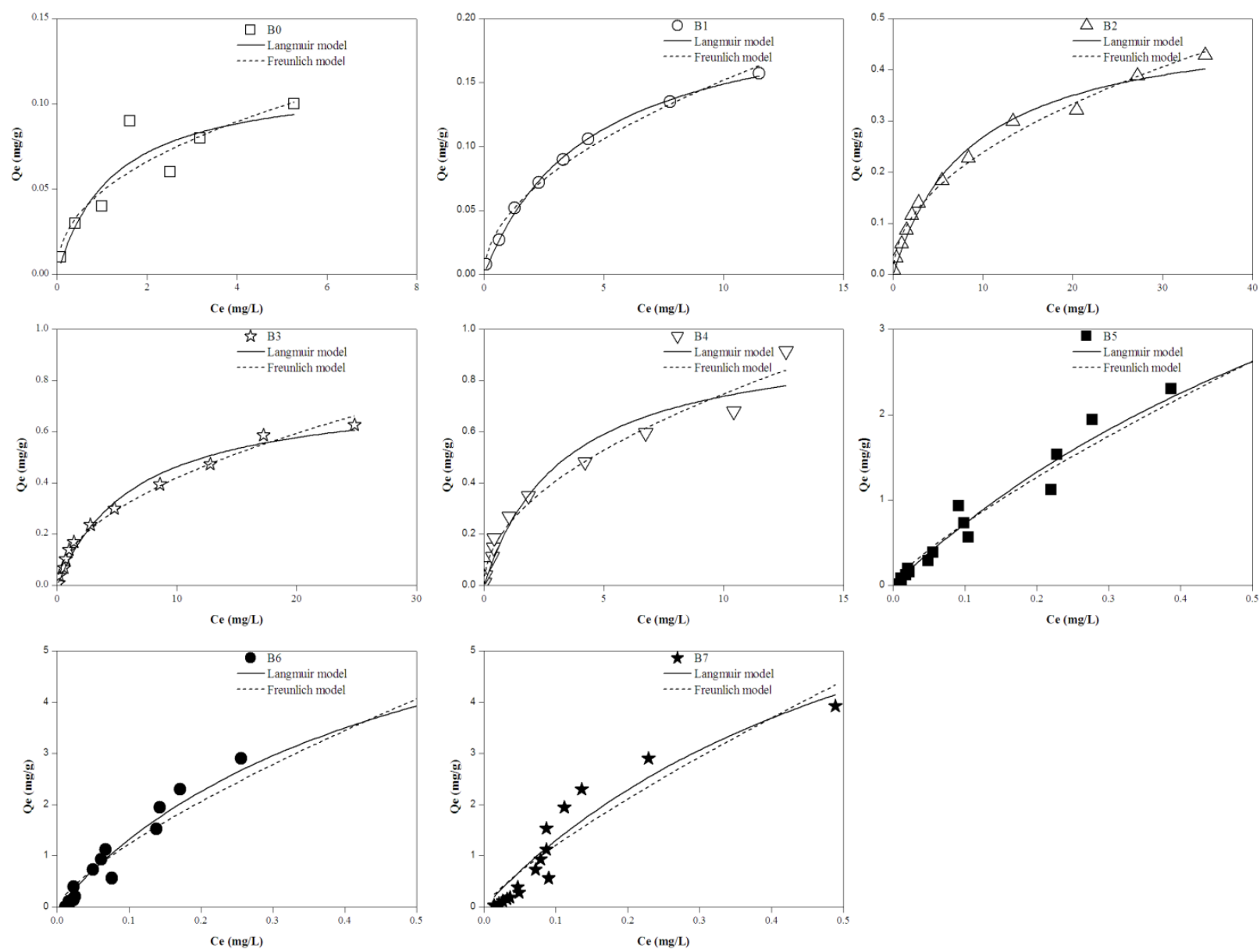

Fig. 2. Adsorption of As on uncoated and Mn-coated bone char samples (equilibrium time 48 h, initial As concentrations $0.05-50 \mathrm{mg} / \mathrm{L})$. 
Table 2. Parameters obtained by Langmuir and Freundlich modeling.

\begin{tabular}{cccccccc}
\hline & \multicolumn{3}{c}{ Langmuir model } & \multicolumn{4}{c}{ Freundlich model } \\
\cline { 2 - 8 } Sample & $\mathrm{Q}_{\max }$ & $\Delta \mathrm{Q}$ & $\mathrm{K}$ & $\mathrm{R}^{2}$ & $\mathrm{~K}$ & $\mathrm{n}$ & $\mathrm{R}^{2}$ \\
\hline $\mathrm{B}_{0}$ & 0.12 & 0.00 & 0.80 & 0.80 & 0.05 & 0.44 & 0.79 \\
$\mathrm{~B}_{1}$ & 0.21 & 0.10 & 0.23 & 1.00 & 0.05 & 0.52 & 0.99 \\
$\mathrm{~B}_{2}$ & 0.50 & 0.39 & 0.11 & 0.98 & 0.08 & 0.48 & 0.99 \\
$\mathrm{~B}_{3}$ & 0.77 & 0.65 & 0.15 & 0.98 & 0.13 & 0.50 & 0.99 \\
$\mathrm{~B}_{4}$ & 0.94 & 0.82 & 0.35 & 0.93 & 0.24 & 0.48 & 0.94 \\
$\mathrm{~B}_{5}$ & 7.55 & 7.44 & 1.06 & 0.97 & 4.57 & 0.80 & 0.97 \\
$\mathrm{~B}_{6}$ & 7.75 & 7.64 & 2.06 & 0.96 & 6.80 & 0.74 & 0.93 \\
$\mathrm{~B}_{7}$ & 9.46 & 9.35 & 1.60 & 0.89 & 7.73 & 0.81 & 0.86 \\
\hline
\end{tabular}

Qmax = adsorption capacity; $\Delta \mathrm{Q}=$ difference between sorption capacity of Mn-coated bone char compared to uncoated bone char; $\mathrm{K}=$ equilibrium constant; $\mathrm{R}^{2}=$ coefficient of determination; $\mathrm{n}=$ constant.

Adsorption equilibrium time is an important control parameter for contaminant treatment, and this in turn affects the practicality and design parameters of PRBs. Arsenic adsorption kinetics on the Mn-coated bone char samples are shown in Fig 3. The data suggest that adsorption rates improve with increased amounts of $\mathrm{Mn}$ on the bone char (e.g., from $0.02 \mathrm{mg} \cdot \mathrm{hr} \mathrm{As}(\mathrm{V})$ per gram bone char for $\mathrm{B}_{0}$ to $0.10 \mathrm{mg} \cdot \mathrm{hr} \mathrm{As}(\mathrm{V})$ for $\left.\mathrm{B}_{7}\right)$.

The filling material of a PRB should have good adsorption performance in the wide $\mathrm{pH}$ range of contaminated water (i.e., to include both acid and alkaline mine drainage). To test this, the effect of $\mathrm{pH}$ on the adsorption of $\mathrm{As}(\mathrm{V})$ was evaluated for $\mathrm{pH}$ values between 4 and 11 . The resultant data shown in Fig. 4 suggest that the adsorption envelope of $\mathrm{As}(\mathrm{V})$ increases with increases in $\mathrm{pH}$ for samples $\mathrm{B}_{0}$ to $\mathrm{B}_{4}$. This result differs from those reported for hydrous ferric oxide and $\mathrm{Al}$ hydroxide (Antelo et al., 2005; Dzombak, 1990). These hydroxides both have good adsorption performances for $\mathrm{As}(\mathrm{V})$ in acidic conditions, but the performance can be significantly reduced due to formation of sorbed protonated arsenate species. On the one side our results suggest that significant dissolution of bone char occurs in low $\mathrm{pH}$ solutions (see section 3.7., below), resulting in the release of $\mathrm{PO}_{4}{ }^{3-}$ from the bone char. It is possible that these $\mathrm{PO}_{4}{ }^{3-}$ ions will then inhibit $\mathrm{AsO}_{4}{ }^{3-}$ adsorption through 
competitive adsorption (Carabante et al., 2010). On the other side, we have determined that the $\mathrm{pH}_{\mathrm{PZC}}$ of the uncoated bone char is 10.8 , suggesting that the surface charge of the bone char will be positive in acidic environments, and thus will promote the chemical adsorption of $\mathrm{AsO}_{4}{ }^{3-}$. Based on the geochemical species diagram of arsenate as function of $\mathrm{pH}$ (Henke, 2009), $\mathrm{H}_{2} \mathrm{AsO}_{4}{ }^{-}$is the dominant species for our study conditions $(\mathrm{pH}=4)$, and the uncharged species $\mathrm{H}_{3} \mathrm{AsO}_{4}{ }^{0}$ gradually becomes the dominant species when $\mathrm{pH}<2$. Therefore, we propose that electrostatic adsorption is the main removal mechanism for $\mathrm{As}(\mathrm{V})$.

High concentrations of $\mathrm{Mn}$ on the bone char (i.e., above $4.85 \mathrm{mg} / \mathrm{kg}$ in samples $\mathrm{B}_{3}$ to $\mathrm{B}_{7}$; Table 1) improve the overall adsorption capacities of arsenic for all $\mathrm{pH}$ conditions (Fig. 3, 4). The As(V) adsorption envelopes for samples $\mathrm{B}_{5}$ to $\mathrm{B}_{7}$ show only slight variations between $\mathrm{pH} 7$ and 11 (Fig. 4). Such stable and good adsorption performance under a wide $\mathrm{pH}$ range is desirable for PRB lifetimes.

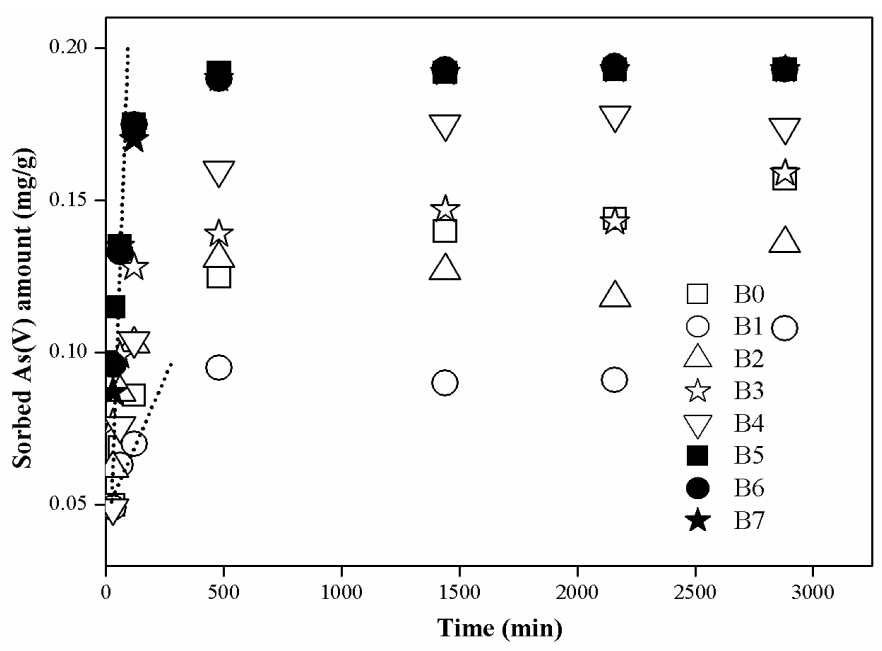

Fig. 3. Adsorption kinetics of As on uncoated and Mn-coated bone char samples (initial $\mathrm{pH} 4$, As concentration 0.5 $\mathrm{mg} / \mathrm{L})$. 


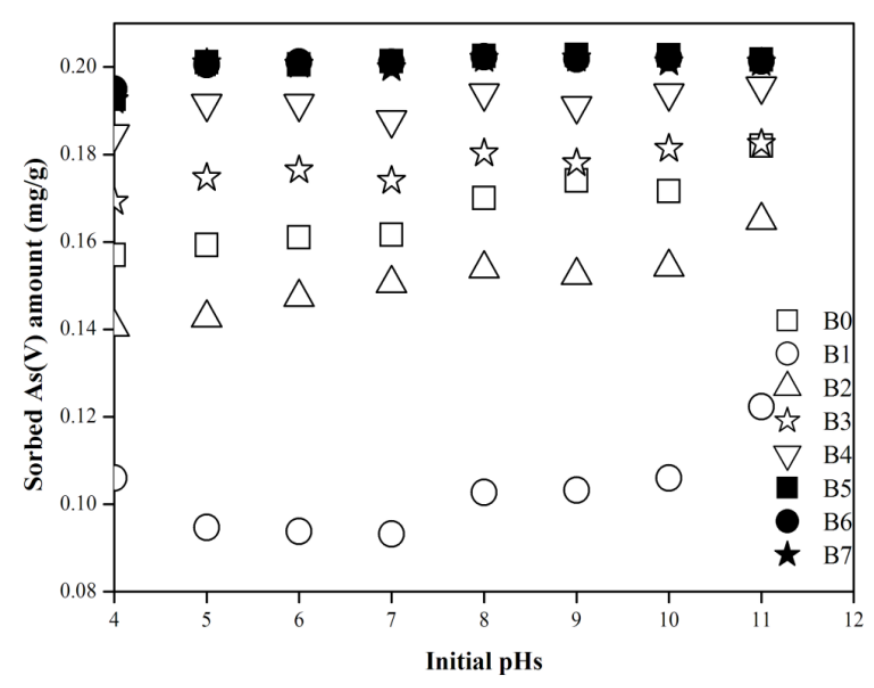

Fig. 4. Variation of As adsorption on uncoated and Mn-coated bone char with initial $\mathrm{pH}$ values (initial As concentration $0.5 \mathrm{mg} / \mathrm{L}$, solid: solution ratio $50 \mathrm{~g} / \mathrm{L})$.

\subsection{Desorption of As(V) on Mn-coated and uncoated bone char}

The filling material of a PRB needs to be considered not only with respect to its adsorption performance, but also with respect to its desorption behaviour. As seen in Fig. 5, 0.3\% of the sorbed As on the uncoated bone char $\left(\mathrm{B}_{0}\right)$ is desorbed at $\mathrm{pH}$ 4. The percentage of desorbed As decreases from $0.06 \%$ to $0.008 \%$ (from $B_{1}$ to $B_{7}$ ) with increases in Mn-coating.

Two desorption behaviours, defined by the steep and shallow slopes of the desorption curves, are evident in Fig. 5. These two curves may reflect two different desorption mechanisms for As on the Mn-coated bone char. The first mechanism may be the desorption of As directly from the bone char, which likely occurs with relatively low loads of As. The second mechanism may be desorption of As from the Mn-bearing coatings, occurring with higher loads of As (1.5-4.0 mg absorbed As/g bone char). 


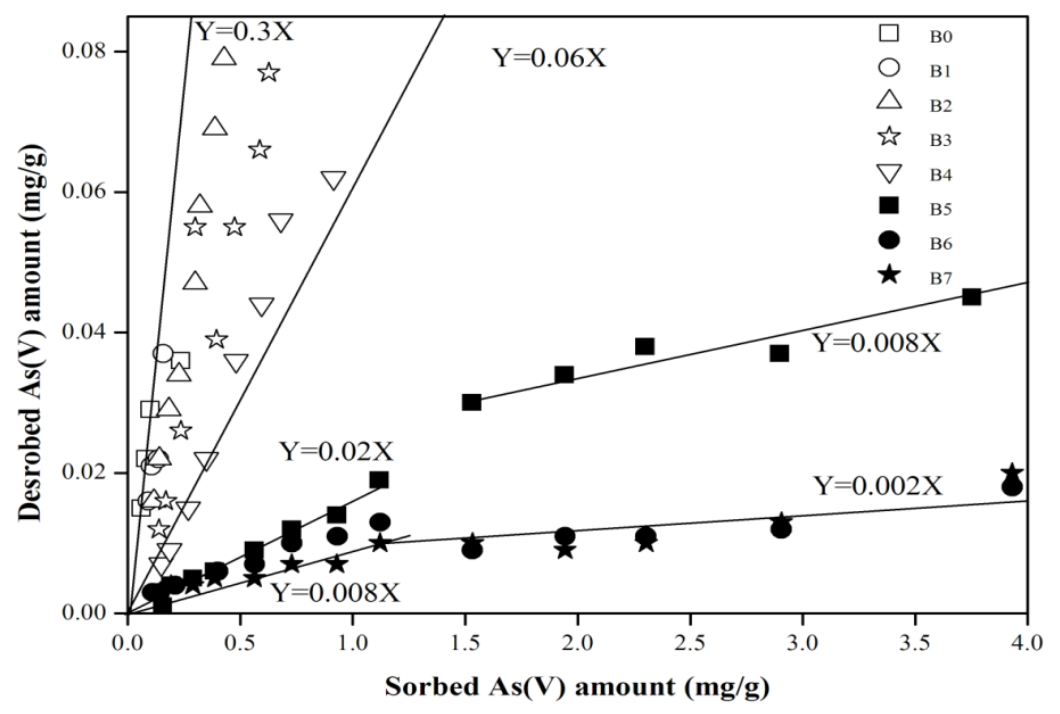

Fig. 5. Desorption of As from As-sorbed uncoated and Mn-coated bone char at $\mathrm{pH} 4$.

\subsection{Breakthrough curves of column experiments}

Coexisting metallic ions such as $\mathrm{Mn}^{2+}$ and $\mathrm{Fe}^{3+}$ will change the performance of a PRB for treatment of AMD or contaminated groundwater. Our previous work has showed that the presence of $\mathrm{Mn}$ ions increases the adsorption ability of $\mathrm{As}(\mathrm{V})$ on bone char compared to coexisting anions (sulfate, silicate and phosphate) (Liu et al., 2014b). To gain more detailed insight in the retardation ability of Mn-coated bone char on $\mathrm{As}(\mathrm{V})$, column experiments were conducted, as these better simulate natural PRB conditions than batch experiments. Breakthrough curves for column experiments using the uncoated and Mn-coated bone char samples and the same As(V) concentrations $(10 \mathrm{mg} / \mathrm{L})$ and flow rates $(213 \mathrm{~mL} / \mathrm{h})$ are given in Fig. 6. The breakthrough curve of the Mn-coated bone char sample with the lowest concentration of $\mathrm{Mn}\left(\mathrm{B}_{1}\right)$ shifts to lower pore volumes than the uncoated bone char $\left(\mathrm{B}_{0}\right)$ (Fig. 6). The corresponding retardation factor for $\left(\mathrm{B}_{1}\right)$ is lower (22.0) than that of $B_{0}$ (44.7), suggesting that the Mn-bearing coating in sample $B_{1}$ passivates the surface by covering adsorption sites on the bone char. However, results from batch experiments show that the maximum adsorption capacity $(\mathrm{mg} / \mathrm{g})$ of $\mathrm{As}(\mathrm{V})$ is higher in sample $\left(\mathrm{B}_{1}\right)(0.21 \mathrm{mg} / \mathrm{g})$ than in sample $B_{0}(0.12 \mathrm{mg} / \mathrm{g})$. Calculated retardation factors for these samples are $62.4\left(\mathrm{~B}_{0}\right)$ and $76.1\left(\mathrm{~B}_{1}\right)$ (Table 3$)$. The breakthrough curves shift progressively to the right (i.e., to higher pore 
volumes) for samples with high concentrations of $\mathrm{Mn}\left(\mathrm{B}_{4}, \mathrm{~B}_{5}, \mathrm{~B}_{6}, \mathrm{~B}_{7}\right)$, suggesting that the retention of $\mathrm{As}(\mathrm{V})$ in the columns increases with increasing $\mathrm{Mn}$. The corresponding calculated retardation factors increase from 56.8 to 246 between $B_{4}$ and $B_{7}, 5.6$ times that of the uncoated bone char. The calculated batch experiment retardation factors are considerably higher than those calculated for the column experiments (compare 114 times to 5.6 times for the uncoated bone char in the batch and column experiments, respectively). These discrepancies could be caused by higher degrees of sorption occurring in the batch experiments due to higher amounts of surface area being exposed compared to the column experiments.

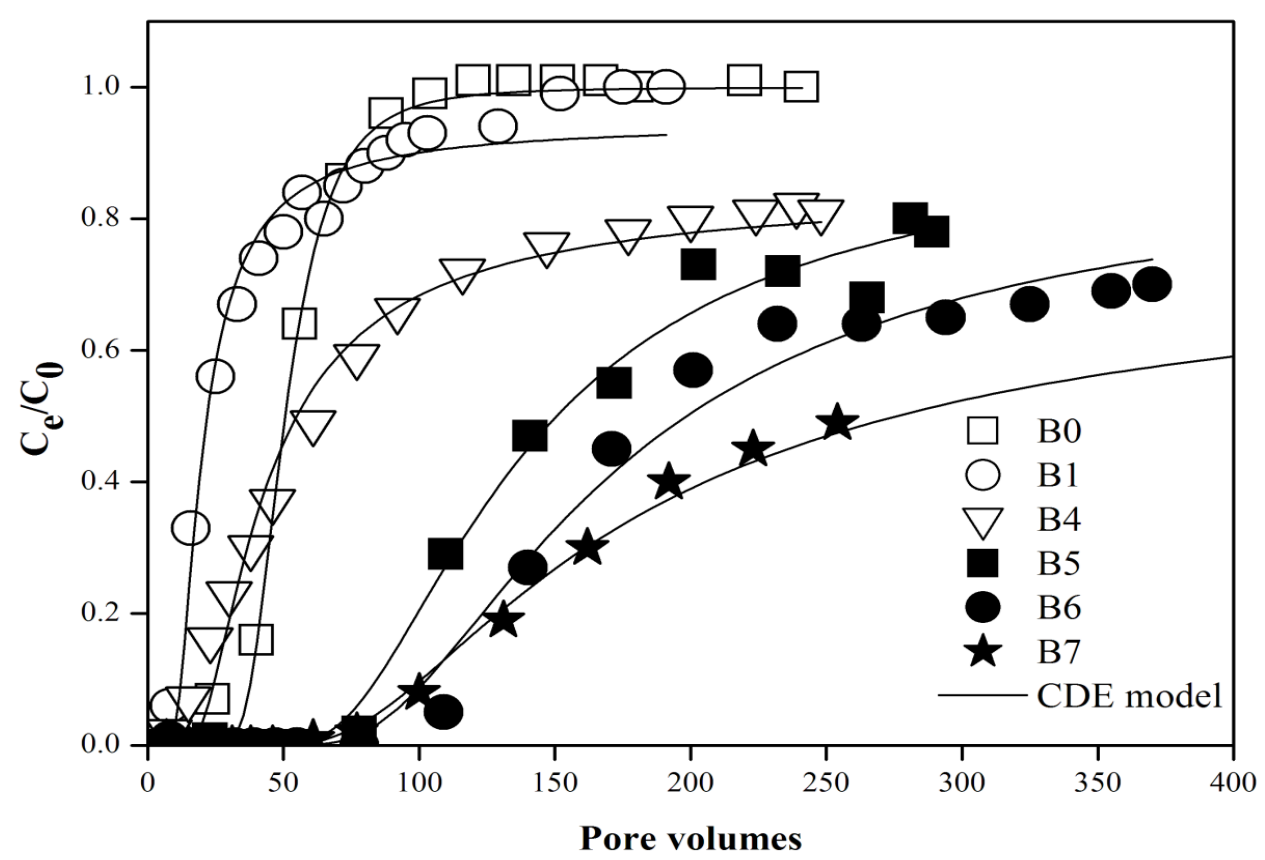

Fig. 6. Breakthrough curves of As(V)-sorbed uncoated and Mn-coated bone char (initial pH value 4, initial As concentration $10 \mathrm{mg} / \mathrm{L}$, flow rate $213 \mathrm{~mL} / \mathrm{h}$ ). 
Table 3. Retardation factors of Mn-coated and uncoated bone char samples calculated using column breakthrough curve and batch experiment data.

\begin{tabular}{cccc}
\hline Sample & $\begin{array}{c}\text { Rfcalculated from column } \\
\text { breakthrough curve }\end{array}$ & $\begin{array}{c}\text { KD calculated from } \\
\text { batch experiments }\end{array}$ & Rf calculated from Eq. 1 \\
\hline $\mathrm{B}_{0}$ & 44.7 & 28.1 & 62.4 \\
$\mathrm{~B}_{1}$ & 22.0 & 34.4 & 76.1 \\
$\mathrm{~B}_{2}$ & Not done & 69.4 & 152 \\
$\mathrm{~B}_{3}$ & Not done & 130 & 286 \\
$\mathrm{~B}_{4}$ & 56.8 & 546 & 1190 \\
$\mathrm{~B}_{5}$ & 151 & 1840 & 4020 \\
$\mathrm{~B}_{6}$ & 198 & 2180 & 4750 \\
$\mathrm{~B}_{7}$ & 246 & 3250 & 7100 \\
\hline
\end{tabular}

Retention factors can be used to quantify the contaminant immobilization performance of media. The retention factor obtained from column experiments can provide a more realistic description of retention than that obtained from batch experiments. The relation between the amount of Mn-coated on bone char $(\mathrm{mg} / \mathrm{g})$ and retention factor of $\mathrm{As}(\mathrm{V})$ in the column experiments is shown in Fig. 7. The retention ability (Y) has a significant linear relation with the amount of $\mathrm{Mn}$ (X), equating to $\mathrm{Y}=15.1 \mathrm{X}+19.8\left(\mathrm{R}^{2}=0.93\right)$. This strong relationship suggests that the Mn-bearing coatings play a more significant role in the retention of $\mathrm{As}(\mathrm{V})$ than the bone char alone. This relationship thus might be a predictor for the retention ability of Mn-coated bone char on As(V). 


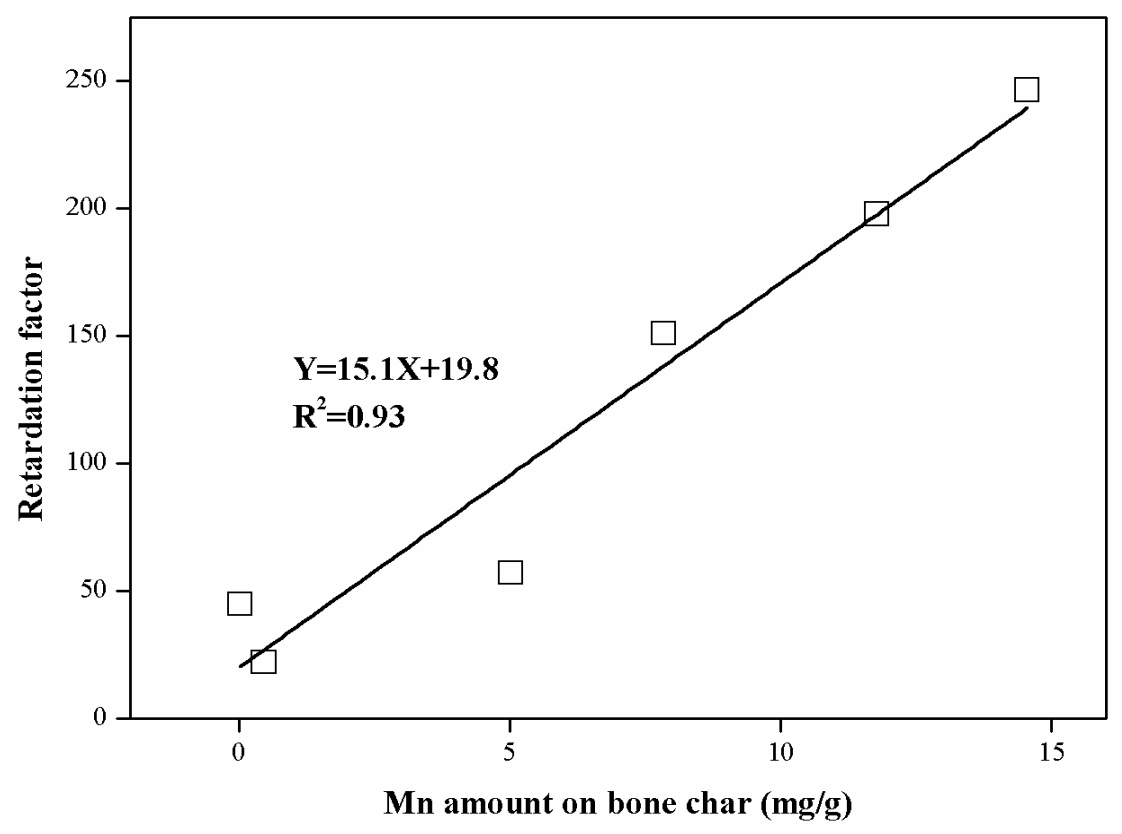

Fig. 7. Relationship between Mn concentration on bone char and retardation factor.

\subsection{Stability of the Mn-coated bone char in acid and alkaline solutions}

The stability of the Mn-coated bone char samples in acid and alkaline solutions was evaluated with solutions of different ionic strengths ( $0 \mathrm{mM}, 0.1 \mathrm{mM}$ and $2 \mathrm{mM})$ and $\mathrm{pH}$ values (2 and 12) (Fig. 8). Ionic strength imposes little effect on Mn release, which implies that the Mn forms a precipitate on the bone char rather than being sorbed to it. This disagrees with a previous study which showed that Mn-coated sand formed by saturated adsorption, with an absorbed concentration of $0.38 \mathrm{mg} / \mathrm{g}$ (Hu et al., 2004). The high amounts of released $\mathrm{PO}_{4}{ }^{3-}$ and the strong neutralization ability of the bone char suggest that this surface precipitate may incorporate phosphate. However, the release of $\mathrm{PO}_{4}{ }^{3-}$ is inhibited for Mn-coated bone char samples with high Mn loads (Fig. 8), suggesting that incorporation of phosphate in these Mn coating is unlikely.

There is also little effect on $\mathrm{Ca}$ and $\mathrm{PO}_{4}{ }^{3-}$ release with ionic strength. Alkaline conditions result in less $\mathrm{Ca}$, $\mathrm{Mn}$ and $\mathrm{PO}_{4}{ }^{3-}$ release to solution than acidic conditions. 

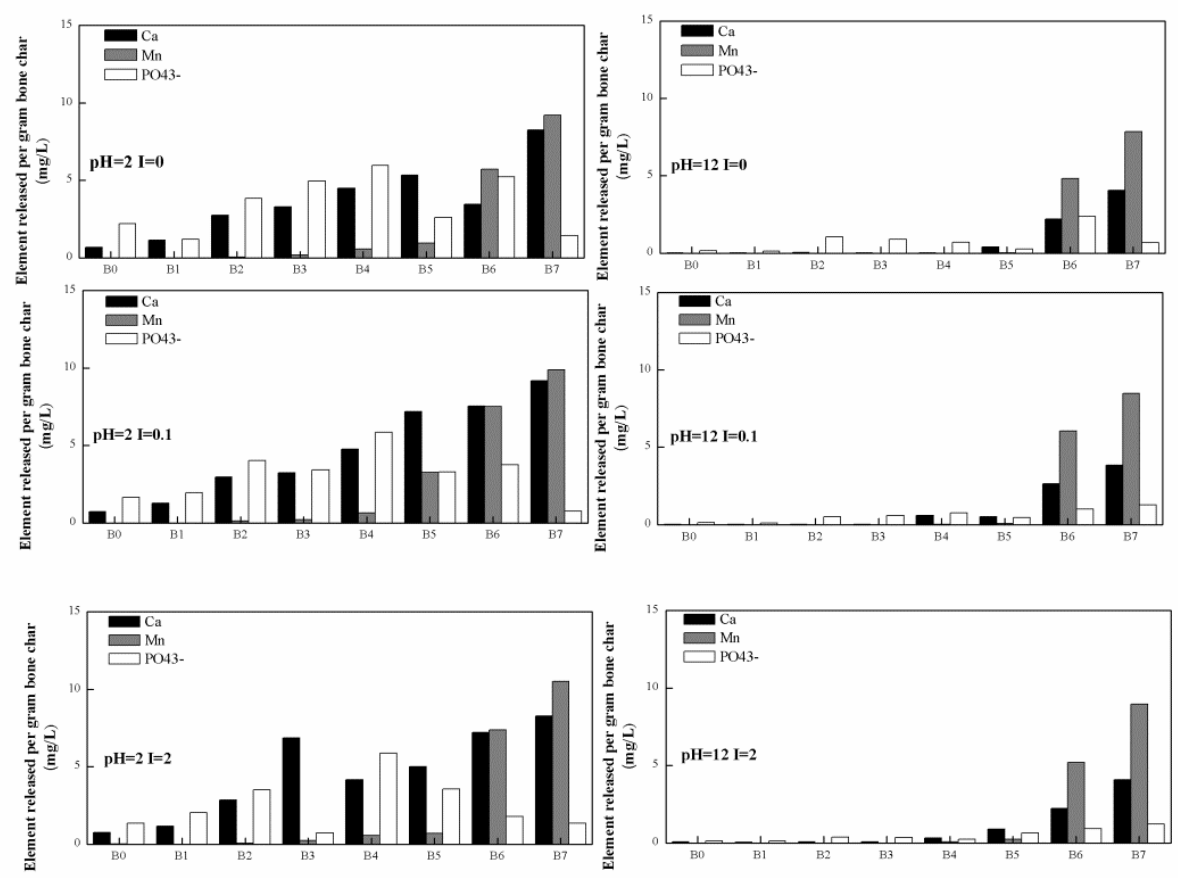

Fig. 8. Release of $\mathrm{Ca}, \mathrm{Mn}$ and $\mathrm{PO}_{4}{ }^{3-}$ from $\mathrm{Mn}$-coated and uncoated bone char under acid and alkali conditions (ionic strength=0, 0.1 and $2 \mathrm{mM} ; \mathrm{pH}$ values $=2$ and 12 ).

\subsection{Neutralization ability of Mn-coated bone char}

It has been suggested that bone char-filled PRBs can neutralize AMD solutions more effectively than limestone-filled PRBs (Liu et al., 2012). Neutralization abilities of the Mn-coated bone char samples were evaluated with respect to time and $\mathrm{pH}$, and significant differences between the $\mathrm{Mn}$ coated bone char samples can be observed in Fig. 9. The $\mathrm{pH}$ values of all of the samples increase rapidly at first, and then decline, with differences in the final $\mathrm{pH}$ values of solutions observed for all the samples. The uncoated bone char gave a final solution $\mathrm{pH}$ of 6.0 , and the Mn-coated bone char sample with the highest concentration of $\mathrm{Mn}$, a final solution $\mathrm{pH}$ of 4.6 . These differences reflect the amounts of Mn nanoparticles that form on the bone char surfaces (Fig. 1). Two steps of the neutralization process were observed in the uncoated bone char $\left(\mathrm{B}_{0}\right)$ and the Mn-coated bone char with the lowest amount of $\mathrm{Mn}\left(\mathrm{B}_{1}\right)$. We suggest that the first step is related to the dissolution of the 
bone char, which contributes hydroxide ions to solution and can thus result in a $\mathrm{pH}$ increase:

$\mathrm{Ca}_{5}\left(\mathrm{PO}_{4}\right)_{3} \mathrm{OH} \rightarrow 5 \mathrm{Ca}^{2+}+3 \mathrm{PO}_{4}^{3+}+\mathrm{OH}^{-}$

Our suggested reaction is supported by the data shown for the acidic $\mathrm{pH}$ dissolution in Figure 8, in which only $\mathrm{Ca}$ and $\mathrm{PO}_{4}{ }^{3-}$ are released for samples $\mathrm{B}_{0}$ and $\mathrm{B}_{1}$.

The second step occurs in $\mathrm{pH}$ windows of 3.5 to 5.8, in which $\mathrm{H}_{2} \mathrm{PO}_{4}{ }^{-}$is the dominant species. We therefore suggest that the second neutralization step is the hydrolysis of phosphate species released from the bone char. This suggestion is supported by the presence of aqueous $\mathrm{PO}_{4}{ }^{3-}$ in the pH 2 digestions (Fig. 8):

$\mathrm{PO}_{4}{ }^{3-}+2 \mathrm{H}_{2} \mathrm{O} \rightarrow \mathrm{H}_{2} \mathrm{PO}_{4}^{-}+2 \mathrm{OH}^{-}$

With higher amounts of $\mathrm{Mn}$ in the coatings the second step becomes less obvious and intense that that seen in $\mathrm{B}_{0}$ and $\mathrm{B}_{1}$, possibly due to lower amounts of released phosphate, or to the uptake of $\mathrm{H}_{2} \mathrm{PO}_{4}{ }^{-}$in secondary Ca- or Mn-bearing precipitates, as suggested by declining amounts of $\mathrm{PO}_{4}{ }^{3-}$ in the acid digestions (Fig. 8), and to a higher mass $\mathrm{Ca}^{2+}: \mathrm{PO}_{4}{ }^{3-}$ ratio for these digestions than the ideal for congruent dissolution of bone char apatite (5:6 in solution). 


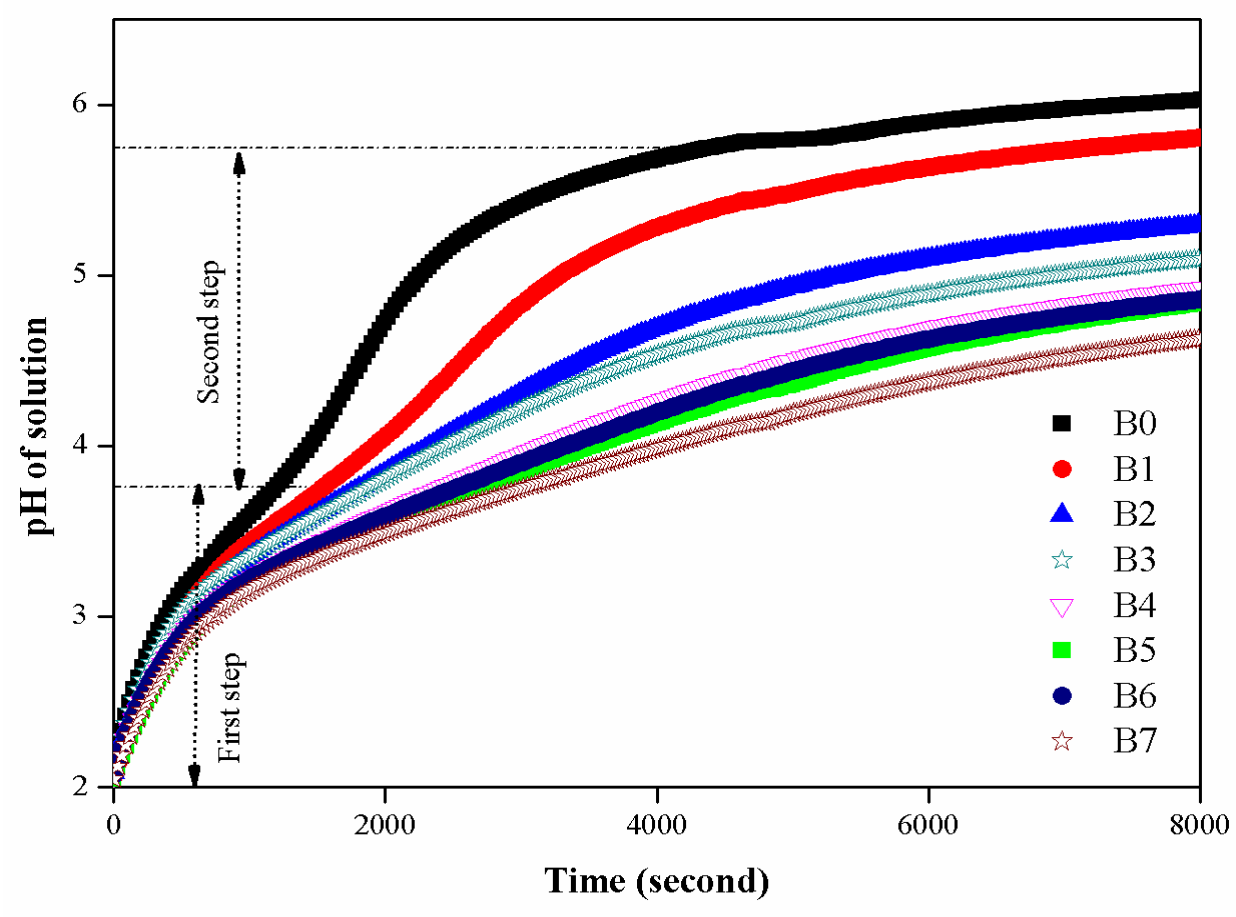

Fig. 9. Neutralization ability of Mn-coated and uncoated bone char

\section{Practical significance for PRBs}

PRB lifetimes are determined by both the treatment performance and by the hydraulic conductivity of the filling material. Apatite has been shown to be a good PRB filling material for remediating AMD or other metalloid- or metal-contaminated ground waters (Choi et al., 1997; Conca and Wright, 2006; Liu et al., 2010; Oliva et al., 2012; Oliva et al., 2011; Sneddon et al., 2005). Our study has shown that, although Mn-coated bone char with low amounts of Mn $(<4.85$ mg/g Mn; Table 1, Fig. 3, 4) decreases the retention of bone char on As(V), bone char with higher amounts of Mn-bearing coatings (>6.79 mg/kg Mn; Table 1, Fig. 3, 4) can improve the retention ability. This suggests that Mn-coated bone char may be a better filling material for PRBs than apatite alone. As our column breakthrough curves have shown that Mn-coated bone char can affect the diffusion behaviour of $\mathrm{As}(\mathrm{V})$, we hypothesise that the retention ability of the Mn-bearing coating will be related to its thickness. Variations in hydraulic conductivity related to the Mnbearing coatings will be addressed by our future work. We will also address the effect of other 
cations and anions in AMD on As(V) retention by Mn-coated bone char.

\section{Conclusions}

Manganese- bearing coatings can be used to improve the retention ability of bone char for As(V), which can increase the lifetime of PRB remediation schemes. This study has shown that:

(1) Mn-coated bone char has up to 78 times more adsorption capacity for $\mathrm{As}(\mathrm{V})$ than uncoated bone char. The maximum adsorption capacity for $\mathrm{As}(\mathrm{V})$ is $9.46 \mathrm{mg} / \mathrm{g}$ at $\mathrm{pH} 4$.

(2) Mn-coated bone char immobilises more $\mathrm{As}(\mathrm{V})$ than uncoated bone char under the same desorption conditions. The desorbed arsenic proportion from the Mn-coated bone char is 0.02$0.6 \%$ of the total sorbed As, which is significantly lower than the proportion for to uncoated bone $\operatorname{char}(30 \%)$.

(3) The retention intensity of As(V) linearly increases with the degree of Mn coating on the bone char, with the retardation factor $(\mathrm{Y})=15.1+\mathrm{X}(\mathrm{Mn}$ concentration in $\mathrm{mg} / \mathrm{g})+19.8$.

(4) The neutralization ability of Mn-coated bone char decreases with the degree of Mn coating of the bone char. The resistance of the Mn-coated bone char to acidic and alkaline solutions is high. Phosphate release from bone char is inhibited compared to calcium, possibly due to the surface precipitation of a $\mathrm{Ca}$ - or $\mathrm{Mn}$-bearing phosphate.

\section{Acknowledgments}

This study was supported by the National Natural Science Foundation of China (Grant No. 41372051). We thank the two reviewers for their insightful comments that improved the manuscript.

\section{References}

Al-Degs, Y.S., El-Barghouthi, M.I., El-Sheikh, A.H., Walker, G.M., 2008. Effect of solution pH, ionic strength, and temperature on adsorption behavior of reactive dyes on activated carbon. 
Dyes and Pigments 77, 16-23.

Antelo, J., Avena, M., Fiol, S., López, R., Arce, F., 2005. Effects of pH and ionic strength on the adsorption of phosphate and arsenate at the goethite-water interface. J. Colloid Interface Sci. 285, 476-486.

Benner, S., Blowes, D.W., Gould, W.D., Herbert, R.B., Ptacek, C.J., 1999. Geochemistry of a permeable reactive barrier for metals and acid mine drainage. Environ. Sci. Technol. 33, 27932799.

Bigham, J.M., Nordstrom,D.K., 2000. Iron and aluminum hydroxysulfates from acid sulfate waters. in: Alpers, C.N., Jambor, J.L., Nordstrom, D.K. (Eds.). Sulfate Minerals: Crystallography, Geochemistry and Environmental Significance Mineralogical Soceity of America, United States of America, pp. 351-403.

Carabante, I., Grahn, M., Holmgren, A., Hedlund, J., 2010. In situ ATR-FTIR studies on the competitive adsorption of arsenate and phosphate on ferrihydrite. J. Colloid Interface Sci. 351, 523-531.

Chang, Y.-Y., Song, K.-H., Yang, J.-K., 2008. Removal of As(III) in a column reactor packed with iron-coated sand and manganese-coated sand. J. Hazard. Mater. 150, 565-572.

Chen, Y.N., Chai, L.Y., Shu, Y.D., 2008. Study of arsenic (V) adsorption on bone char from aqueous solution. J. Hazard. Mater. 160, 168-172.

Choi, J.C., West, T.R., Seol, Y., 1997. Application of MINTEQA2 to the evaluation of apatite as a precipitant for acid mine drainage treatment. Environ. Eng. Geosci. 3, 217-223.

Clesceri, L.S., Greenberg, A.E., Trussel, R.R., 1989. Standard Methods for the Examination of Wastewater. American Public Health Association, Port City Press, Baltimore, Maryland, pp. 4166.

Conca, J.L., Wright, J., 2006. An apatite II permeable reactive barrier to remediate groundwater containing Zn, $\mathrm{Pb}$ and Cd. Appl. Geochem. 21, 1288-1300.

Davis, A., Webb, C., Dixon, D., Sorensen, J., Dawadi, S., 2007. Arsenic removal from drinking 
water by limestone-based material. Min. Eng. 59, 71-74.

Dzombak, D.A., 1990. Surface complexation modeling: hydrous ferric oxide. John Wiley \& Sons. Gibert, O., de Pablo, J., Cortina, J.-L., Ayora, C., 2010. In situ removal of arsenic from groundwater by using permeable reactive barriers of organic matter/limestone/zero-valent iron mixtures. Environ. Geochem. Health 32, 373-378.

Gu, Z., Fang, J., Deng, B., 2005. Preparation and evaluation of GAC-based iron-containing adsorbents for arsenic removal. Environ. Sci. Technol. 39, 3833-3843.

Guo, H., Wen, D., Liu, Z., Jia, Y., Guo, Q., 2014. A review of high arsenic groundwater in Mainland and Taiwan, China: Distribution, characteristics and geochemical processes. Appl. Geochem. 41, $196-217$.

Heidari, M., Moattar, F., Naseri, S., Samadi, M., Khorasani, N., 2011. Evaluation of aluminumcoated pumice as a potential arsenic(V) adsorbent from water resources. Int. J. Environ. Res. 5, 447-456.

Henke, K. (2009) Arsenic: Environmental Chemistry, Health Threats and Waste Treatment. John Wiley and Sons, Chichester, UK.

Hu, P.Y., Hsieh, Y.-H., Chen, J.-C., Chang, C.-Y., 2004. Characteristics of manganese-coated sand using SEM and EDAX analysis. J. Colloid Interface Sci. 272, 308-313.

Li, M.H., Wang, T.H., Teng, S.P., 2009. Experimental and numerical investigations of effect of column length on retardation factor determination: A case study of cesium transport in crushed granite. J. Hazard. Mater. 162, 530-535.

Liu, G., Talley, J.W., Na, C., Larson, S.L., Wolfe, L.G., 2010. Copper doping improves hydroxyapatite sorption for arsenate in simulated groundwaters. Environ. Sci. Technol. 44, 13661372.

Liu, J., Cheng, H., Zhao, F., Dong, F., Frost, R.L., 2012. Effect of reactive bed mineralogy on arsenic retention and permeability of synthetic arsenic-containing acid mine drainage. J. Colloid Interface Sci. 394, 530-538. 
Liu, J., Huang, X., Liu, J., Wang, W., Zhang, W., Dong, F., 2014a. Adsorption of arsenic (V) on bone char: batch, column and modeling studies. Environ. Earth Sci. 72, 2081-2090.

Liu, J., Huang, X., Liu, J., Wang, W., Zhang, W., Dong, F., 2014b. Experimental and model studies on comparison of As(III and V) removal from synthetic acid mine drainage by bone char. Miner. Mag. 78, 73-89.

Logue, B.A., Smith, R.W., Westall, J.C., 2004. U (VI) adsorption on natural iron-coated sands: comparison of approaches for modeling adsorption on heterogeneous environmental materials. Appl. Geochem. 19, 1937-1951.

Maji, S.K., Kao, Y.-H., Liu, C.-W., 2011. Arsenic removal from real arsenic-bearing groundwater by adsorption on iron-oxide-coated natural rock (IOCNR). Desalination 280, 72-79.

Maji, S.K., Kao, Y.-H., Wang, C.-J., Lu, G.-S., Wu, J.-J., Liu, C.-W., 2012. Fixed bed adsorption of As (III) on iron-oxide-coated natural rock (IOCNR) and application to real arsenic-bearing groundwater. Chem. Eng. J. 283, 285-293.

Maliyekkal, S.M., Sharma, A.K., Philip, L., 2006. Manganese-oxide-coated alumina: a promising sorbent for defluoridation of water. Water Res. 40, 3497-3506.

Manning, B.A., Fendorf, S.E., Bostick, B., Suarez, D.L., 2002. Arsenic (III) oxidation and arsenic (V) adsorption reactions on synthetic birnessite. Environ. Sci. Technol. 36, 976-981.

Nordstrom, D.K., 2011. Mine waters: acidic to circumneutral. Elements 7, 393-398.

Oliva, J., Cama, J., Cortina, J.L., Ayora, C., De Pablo, J., 2012. Biogenic hydroxyapatite (Apatite

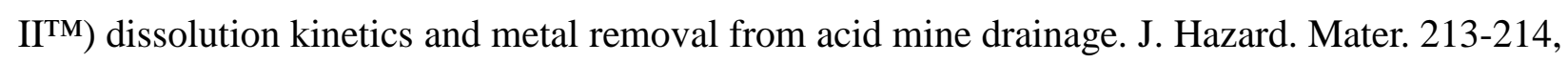
7-18.

Oliva, J., De Pablo, J., Cortina, J.L., Cama, J., Ayora, C., 2010. The use of Apatite II (TM) to remove divalent metal ions zinc(II), lead(II), manganese(II) and iron(II) from water in passive treatment systems: Column experiments. J. Hazard. Mater. 184, 364-374.

Oliva, J., De Pablo, J., Cortina, J.L., Cama, J., Ayora, C., 2011. Removal of cadmium, copper, nickel, cobalt and mercury from water by Apatite II (TM): Column experiments. J. Hazard. 
Mater. 194, 312-323.

Robinson, B.C., 2010. Mine Drainage and Related Problems. Nova Science Publishers, Inc., New York. Santoro, L., Volpicelli, G., Caprio, V., 1987. Limestone neutralization of acid waters in the presence of surface precipitates. Water Res. 21, 641-647.

Rötting, T.S., Caraballo, M.A., Serrano, J.A., Ayora, C., Carrera, J., 2008a. Field application of calcite Dispersed Alkaline Substrate (calcite-DAS) for passive treatment of acid mine drainage with high Al and metal concentrations. Appl. Geochem. 23, 1660-1674.

Rötting, T.S., Thomas, R.C., Ayora, C., Carrera, J., 2008b. Passive treatment of acid mine drainage with high metal concentrations using dispersed alkaline substrate. J. Environ. Qual. 37, 17411751.

Santoro, L., Volpicelli, G., Caprio, V., 1987. Limestone neutralization of acid waters in the presence of surface precipitates. Water Res. 21, 641-647.

Sicupira, D., Silva, T.T., Leão, V., Mansur, M., 2014. Batch removal of manganese from acid mine drainage using bone char. Brazilian J. Chem. Eng. 31, 195-204.

Sikora, F., Behrends, L., Brodie, G., Taylor, H., 2000. Design criteria and required chemistry for removing manganese in acid mine drainage using subsurface flow wetlands. Wat. Environ. Res. 536-544.

Sneddon, I., Garelick, H., Valsami-Jones, E., 2005. An investigation into arsenic (V) removal from aqueous solutions by hydroxylapatite and bone-char. Miner. Mag. 69, 769-780.

Tournassat, C., Charlet, L., Bosbach, D., Manceau, A., 2002. Arsenic (III) oxidation by birnessite and precipitation of manganese (II) arsenate. Environ. Sci. Technol. 36, 493-500. 